\title{
Technologies of Distance Learning for Teaching Primary School Subjects of During the COVID-19 Pandemic
}

\author{
Liudmyla Havrilova * [0000-0003-1814-5323], Olena Beskorsa ${ }^{[0000-0001-8018-8549]}$
}

\author{
Department of Primary Education Theory and Practice, SHEI “Donbas State Pedagogical University”, Sloviansk, \\ Ukraine \\ *havrilovalg@gmail.com
}

\begin{abstract}
The paper presents a research of implementing the special course "Technologies of Distance Learning for Teaching Primary School Subjects" in the pre-service primary school teachers' professional training. The relevance of the study is caused by teachers' unpreparedness to effectively organise distance learning that is proved by the survey, conducted by the civil organisation. The theoretical background of the research includes the approaches and principles that are typical for distance education. The content of the implemented course is developed, taking into account the requirements to pre-service primary school teachers' knowledge and skills which must be developed during the professional training. After studying the course "Technologies of Distance Learning for Teaching Primary School Subjects", the survey has been conducted among students which prove the effectiveness of its implementation according to the higher motivation level.
\end{abstract}

Keywords: Distance learning, Pre-service primary school teachers, Professional training, Distance course.

\section{INTRODUCTION}

The development of distance education in Ukraine is mainly caused by world processes of globalization and informatisation: the evolution of the traditional system of education from the blackboard to the computer learning systems, from the paper book library to the electronic one, from the traditional class to the virtual one forces the implementation of distance learning technologies at all education stages.

The important factor of increasing the attention to distance education in Ukraine in the middle of the 2010s became the Concept of New Ukrainian School which since 2016 has encouraging the teachers of all the education stages to immerse themselves in the features of distance learning, to create their electronic learning resources for their learning and teaching means.

The second significant factor is the COVID-19 pandemic when the quarantine was introduced at schools and distance learning became the only way of providing educational services. At the same time, the following facts are revealed: firstly, most teachers of secondary schools turn to be unprepared to effectively work in the distance form, secondly, the quality of the distance learning is insufficient despite a great number of forms, tools, and models of distance learning.

The State Service of Education Quality and the workers of the civil organization "ProSvit" researched on the process of implementing distance learning in all the regions of Ukraine on the process at the end of 2019 2020 academic year. It was revealed that more than half of parents, who participated in the survey, had a negative attitude to distance learning [1].

The most common problems of implementing distance learning are: the lack of pupils' interest in distance learning (72,6\% of respondents); the absence of previous experience to use distance learning tools in classes and the difficulties in organising on-line lessons (49,6\% of respondents), etc. The surveys have also proved that the significant obstacle for getting an education in distance is the absence of a unified online platform that greatly overloads pupils and parents who have to adapt to every teacher's requirement. About 50\% of respondents say that the key problem in implementing distance learning is the absence of previous experience. The statistical data and respondents' answers disclose 
that the education institutions with the developed information and communication learning environment (for example, "Atmospheric school", Kyiv, Ukraine) effectively implements distance learning in the conditions of quarantine restrictions [1].

The issue of the quality of educational services in the conditions of learning in distance is studied by scientists in many countries. So, M. M. Hassan \& T. Mirza [2] study the factors that cause teachers' unwillingness to use ICT in classes and events which influence the successful integration of ICT into the learning process in the schools of Rajouri district (J\&K, India). The scientists conclude that there is an urgent need to develop teachers' digital literacy for creating the learning environment and contributing to the development of the creativity, metacognition, metaliteracy, collaboration, and communication of pupils.

The problem of the unpreparedness to distantly work concerns both practicing teachers and students, who are studying at higher education institutions to gain the professional of a teacher. There is an urgent need in training the specialists who will be able to effectively work at school in the nearest future, using the present arsenal of distance learning tools. That is why the special course "Technologies of Distance Learning for Teaching Primary School Subjects" has been developed at SHEI "Donbas State Pedagogical University" (Sloviansk, Ukraine) for training the pre-service teachers of the speciality 013 Primary Education, aimed at preparing the specialists to organise the distance learning, taking into account the specificity of primary school age (the priority significance of the visual tools, interest in learning in the game form, etc.). So, the purpose of this research is to analyse the experience of developing and implementing the special course "Technologies of Distance Learning for Teaching Primary School Subjects".

\section{RESEARCH METHODS}

The scientific-theoretical and methodological background of the research includes the key approaches: 1) the competence-based approach as a key educational paradigm of the latest decade is a strategic direction of state policy in the sphere of education, reforming the education system in Ukraine, modernising its structure and content that is considered to be an attempt to bring the education system in line with the needs of the labour market; 2) the information one that is connected with developing the information provision, developing and functioning the digital learning environment of preservice primary school teachers' professional training; 3 ) the interdisciplinary one, which realises the modern strategy of modernizing professional-pedagogical training of future teachers of New Ukrainian school on the basis of the integration; 4) the activity-based one that is connected with future specialists' activities, using the gained theoretical knowledge in the practice, the successful integration in the society and professional selfrealisation.

As distance education is based on the principles of education modernisation and the wide use of digital communication, the scientific-theoretical basis of the research includes a number of the special principles: the principle of the creative characteristic of cognitive activities; the principle of free choice of received information by the defined activities; the principle of individualising students' educational activities; the principle of virtualising the education and systematic structuring of the information; the principle of creating students' educational products; the principle of the interactivity; the multimedia-based principle. These principles are based as a result of generalising the theoretical findings of O. Beskorsa [3], L. Havrilova [4], V. Kukharenko [5], F. Chetwynd \& Dobbyn C. [6], H. Park \& P. Shea [7], T. Surma \& P. Kirschner [8], who study the theory and practice of the distance education.

The empirical research methods include the survey of higher education students' survey, which takes place at the end of studying the special course "Technologies of Distance Learning for Teaching Primary School Subjects", focused on assessing the motivation to use distance learning tools. The survey (the questions in the form of statements and simple problem situations which should be agreed or disagreed) is built on the basis of the adaption of methods of diagnosing the motivation to the achievement of the success of T. Ellers [9] and conducted with the use of Google Form (https://cutt.ly/GkulWIN). 32 four-year students of the Faculty of Primary, Technological, and Vocational Education at SHEI "Donbas State Pedagogical University" (day and parttime studying). 15 students (day study) attend the classes of the special course "Technologies of Distance Learning for Teaching Primary School Subjects" and comprise the experimental research group (ERG); 17 students (parttime study) study at the classic program and comprise the control research group (CRG). Making experimental and control research group, students' average mark of success and knowledge quality of the previous session has been taken into account. So, the requirements to sample homogeneity of surveyed students at higher education institutions have been met. Four levels of students' motivation to use distance learning tools (see table 1) are distinguished according to the number of obtained marks.

\section{RESEARCH RESULTS}

The implementation of the course "Technologies of Distance Learning for Teaching Primary School Subjects" is caused by the necessity to improve the quality of professional training of Bachelor students of speciality 013 Primary Education, in particular the effective implementation of distance technologies, the use of modern opportunities of computer networks and distance learning systems, that is future specialists' 
training to work in distance educational environment. The important theoretical background for developing the course includes the foreign and national concepts, modern state initiatives in the sphere of education globalisation and informatisation, scientific research on creating and using ICT tools in pedagogical activities.

The scientific and theoretical basis and main principles of practical organisation of activities in the Moodle learning environment on the courses of main primary school subjects are defined and characterized in the course "Technologies of Distance Learning for Teaching Primary School Subjects". The activities with additional distance learning tools (mind maps, interactive posters, test programs, etc.) are described. Studying the course is aimed at developing future teachers' professional readiness to use distance learning tools.

After studying the course, pre-service primary school teachers know: the content of distance learning as a specific form of gaining the education, its essence, functions, advantages, and disadvantages; the regulatory documents on organising the distance learning, system of learning management (distance learning platforms), their variants; the features of an electronic learning resource, peculiarities of their effective use in the learning process; the principles of designing the distance course and learning resources for distance education; the features of work with infographics, interactive posters, animated presentations, and programs for their creating.
After studying the course, pre-service primary school teachers acquire the following skills: to perfectly use computer equipment and multimedia learning resources, as well as to reasonably use them in future professional activities; to use the advantages of the distance learning system Moodle in the process of studying primary school subjects; to select and create the learning and teaching provisions for primary school classes with the use of auxiliary distance learning technologies; to look for and select the information in global network Internet; to actively work in the information and communication learning environment on the basis of using the principles of blended learning.

So, we offer the general structure of the course "Technologies of Distance Learning for Teaching Primary School Subjects": Module 1. Theoretical foundations of using distance learning technologies while teaching primary school subjects; Module 2. The use of the auxiliary distance learning technologies in primary school classes. The content of the seminars in the course "Technologies of Distance Learning for Teaching Primary School Subjects" contains the organisation and realisation of the search on the internet, the familiarisation with distance learning, distance course, its structure and content in Moodle system, tests in Moodle, work with auxiliary distance learning technologies, the development of infographics, presentations, interactive posters, and animated presentations (Cacoo, MS PowerPoint, Prezi, Powtoon, etc).

Table 1. The levels of motivation of ERG and CRG students to use the distance learning tools

\begin{tabular}{|c|l|}
\hline $\begin{array}{c}\text { Low level } \\
(0-10 \text { points })\end{array}$ & $\begin{array}{l}\text { Pre-service primary school teachers' inert attitude to using distance learning tools. Insufficient } \\
\text { motivation to acquiring the theory and methodology of organising primary schoolchildren's } \\
\text { distance learning by distance learning tools. The spontaneity of motivation and situational } \\
\text { interest to using distance learning tools while studying and doing further professional } \\
\text { activities. The desire for professional growth and self-improvement is absent. }\end{array}$ \\
\hline $\begin{array}{c}\text { Medium level } \\
\text { (11-16 points) }\end{array}$ & $\begin{array}{l}\text { The interest in modern information and communication technologies, in particular distance } \\
\text { technologies, is present, however, the awareness of their importance as a tool of professional } \\
\text { activities doesn't go behind the learning content. The students have a generally positive and } \\
\text { active attitude to using distance learning in pedagogical activities, but a weak desire to } \\
\text { broaden their knowledge in this sphere. }\end{array}$ \\
\hline $\begin{array}{c}\text { Sufficient level } \\
(17-20 \text { points })\end{array}$ & $\begin{array}{l}\text { The constant professional and cognitive interest in distance learning tools, the positive attitude } \\
\text { to the pedagogical activities, and the acquirement of theory and methodology of teaching with } \\
\text { the use of information and communication (digital) technologies are present. The students } \\
\text { have a desire to self-education and broadening the experience to use distance technologies. }\end{array}$ \\
\hline $\begin{array}{c}\text { High level } \\
\text { (21 points and } \\
\text { more) }\end{array}$ & $\begin{array}{l}\text { The awareness of the necessity to use distance learning tools in professional activities and the } \\
\text { ability to express their point of view to others are present. The students need professional self- } \\
\text { realisation in the sphere of using distance technologies. }\end{array}$ \\
\hline
\end{tabular}

The independent work of pre-service primary school teachers in the course "Technologies of Distance Learning for Teaching Primary School Subjects" includes the assignments which are focused on the maximum motivation and engagement of pre-service primary school teachers in the activities in the distance learning environment: working with the internet sources; working in the Moodle system; developing infographics, interactive posters, and animated presentations with the use of free services on the Internet; developing tests for carrying out interim and final control, processing, and analysing the test results. 
The special course is supported by the appropriate distance course in the Moodle distance learning system at SHEI "Donbas State Pedagogical University". The distance course for pre-service primary school teachers is developed, taking into account the well-known model of developing pedagogical scenario of a learning course for electronic learning environment ADDIE that contains five stages: the analysis of the content, a learning environment, defining the academic subject and the opportunities of the hardware and software; the designing (determining the learning outcomes, teaching methods and ways of assessing, detailing the content and the topics); the development (preparing all the learning materials, assignments, topics, projects, etc., planning the organization of the course and its uploading in the learning management system); the implementation (conducting the learning, organization of the interaction with students); the assessment (defining if the aims are achieved and if the content and learning methods require being adjusted) [10].

The suggested distance course includes a number of ways of delivering information, including e-mail, audio and video materials, as well as the tools that are available within this distance learning platform (Moodle). The course is developed with the use of synchronous learning methods that make it more flexible and mobile and give an opportunity for students to choose the suitable time of working on the course materials.

The work in the distance course is done in the following way: students study theoretical material of lecture and video fragments; they get prepared for seminars, place the assignments completed in the forums, created for these assignments, where they can assess the assignments of their groupmates; they do the tasks for independent fulfilling and sending them in the distance learning platform; some themes include the interim control which helps students show their theoretical knowledge. After studying the course, students participated in the final tests.

The distance course "Technologies of Distance Learning for Teaching Primary School Subjects" has an introductory, theoretical (information), practical, and control part. Studying in the distance course "Technologies of Distance Learning for Teaching Primary School Subjects" finishes the exit tests that include different types of tasks. The survey conducted among ERG and CRG four-year students after studying the course at the Faculty of Primary, Technological and Vocational Education of SHEI "Donbas State Pedagogical University" shows that more students have a higher level of motivation and desire to work in the conditions of distance learning experimental research group (Table 2).

The analysis of gained results makes it possible to state more passive attitude of CRG students to use distance learning tools, which, to our mind, results in the professional impossibility of pre-service primary school teachers to work in the conditions of modernisation and informatisation of the educational process. A significant amount of these students don't consider distance learning as a full-fledged way to gain education, they are not motivated to acquiring the additional services to make electronic learning resources. Most CRG students claim that they like classroom lessons more than distance ones; it's comfortable to the assignments in classes, but not in the distance form. So, it's difficult for students to leave the traditional learning format.

At the same time ERG students, who have studied the special course "Technologies of Distance Learning for Teaching Primary School Subjects", say that they are interested in working in the distance course, making electronic learning resources for school children and in working with them in the distance format.

Table 2. Levels of ERG and CRG students' motivation to use distance learning tools after implementing the course

\begin{tabular}{|c|c|c|c|c|}
\hline \multirow[t]{2}{*}{ Levels } & \multicolumn{2}{|c|}{ Control research group (17 persons) } & \multicolumn{2}{|c|}{ Experimental research group (15 persons) } \\
\hline & $\begin{array}{l}\text { Number of } \\
\text { respondents, absolute } \\
\text { number }\end{array}$ & $\begin{array}{l}\text { Number of } \\
\text { respondents, \% }\end{array}$ & $\begin{array}{l}\text { Number of } \\
\text { respondents, absolute } \\
\text { number }\end{array}$ & $\begin{array}{l}\text { Number of } \\
\text { respondents, \% }\end{array}$ \\
\hline Low & 5 & 29,4 & 2 & 13,3 \\
\hline Medium & 6 & 35,3 & 3 & 20 \\
\hline Sufficient & 4 & 23,5 & 7 & 46,7 \\
\hline High & 2 & 11,8 & 3 & 20 \\
\hline
\end{tabular}

\section{DISSCUSSION}

A lot of latest scientific findings concern the necessity to deeply study the features of distance learning by future specialists, taking into account the specificity of each profession in the conditions of distance learning, the use of specific methods, acquiring new forms of digital communication and modern software for improving the effectiveness of distance learning. The number of scientific papers in this sphere has greatly increased when the education system of most world countries has transitioned to distance format in the conditions of the current epidemiological situation, caused by the Coved19 pandemic. 
We totally agree with T. Surma \& P. Kirschner [7], who assert that the use of distance learning tools has a considerable advantage, however, the educators turn to be unprepared to such a sudden transition to the distance learning format during the Covid-19 pandemic. As a result of the search and analytical activities, scientists have distinguished three key principles of learning in the distance which should be initially improved for effective work in the distance environment: providing clear guidance using worked examples and optimal use of multimedia principles; providing sample chances for practice and feedback; assisting students on their pathway to successful individual learning [7].

In our opinion, these principles of learning in distance fully correspond to the components of digital literacy, defined by D. Belshaw in the book "The Essential elements of digital literacies" [11]. The scientist singles out eight key components (8C) as a basis for the quality interaction between human and digital technologies (Cultural: how to behave; Cognitive: how to do; Constructive: how to use; Communicative: how to communicate; Critical: how to evaluate; Civic: how to participate; Confident: how to belong; Creative: how to make). A personality's developed digital culture ensures successful work in the distance environment (L. Havrilova \& Y. Topolnik [12]), that is following certain behaviour rules by a person while using information and communication technologies, including the distance one.

Thus, distance learning requires the developed digital literacy and digital culture as a system of a person's behaviour in the conditions of a digital society that includes the communication culture (Webcommunication, Network Etiquette), the rational use of information (media literacy), the developed skills of critical thinking and of effective use of digital technologies for ensuring personal needs and successful professional activities.

The search for the optimal combination of synchronous and asynchronous, online and offline learning methods is relevant in scientific researches of forms and methods of distance learning. E. G. Dada, A. H. Alkali, D. O. Oyewola [13], studying how synchronous and asynchronous electronic learning influences the students' success, rightly claim that there is an urgent need to organically combine these learning modes. The scientists who investigate the theory and practice of blended learning share this viewpoint: I. Thomson [14], D. Clark [15], V. Purnima [16], and others express their ideas concerning blended learning in the early 2000s, defining it as an effective learning form. They consider this form to be the combination of traditional formal learning tools - work face-to-face, studying theoretical material - with an informal discussion of the material in the blog, forum, using mobile devices, e-mails, webinars, internet-conferences, etc. So, blended learning includes the independent acquiring of the theoretical material (for example, in electronic learning course) and the certain abilities and skills are trained and improved in auditorium classes that are implemented with the use of various methods and forms of collaboration (D. Clark [15]). V. Kukharenko rightly claims that blended (hybrid) learning is one of the most popular technologies, as it allows to use the flexibility and convenience of a distance course, as well as the advantages of a traditional course [5]. Most researchers of distance learning think that this learning form will be the dominant one after finishing the Covid19 pandemic.

We think it's necessary to emphasise the statement of V. Purnima [16], who says that blended learning is a system of combining different learning forms: face-toface, live e-learning, and self-paced learning. Blended learning allows to combine formal and non-formal learning, traditional and distance learning that opens the space for implementing new ideas and technologies.

The research of the team of authors from Vocational High School in Taiwan (Chin-Ting Chou, Chien-Pen Chuang, Bin-Yong Zheng [17]) turns to be interesting. They try to study the optimal proportion of face-to-face and digital learning. The gained results have shown that the optimal learning effect is achieved in the time proportion 2:1 of traditional face-to-face teaching and digital learning.

O. Barabash, A. Musienko, and others [18] suggest a complex approach to assessing the effectiveness of the distance learning process, based on the methods of probability theory and hierarchy analysis. They were encouraged to start the research by the fact that scientists usually assess the effectiveness of single elements of the distance learning system and appropriate quality indicators. The scientists develop their methodology of assessing the effectiveness of distance learning system, based on the complex analysis of its constituent parts: regulatory, organizational, scientific-methodological, information and telecommunications, mathematical and software, logistics, personnel, financial and economic support.

\section{CONCLUSIONS}

The analysis of the results of implementing the special course "Technologies of Distance Learning for Teaching Primary School Subjects", supported by the corresponding distance course in the Moodle system of SHEI "Donbas State Pedagogical University" (Sloviansk, Ukraine), makes it possible to make the conclusions on improving the professional training of the specialists in the sphere of primary education during the Covid-19 pandemic. They are: 1) increasing the digital literacy and digital culture of both school and higher education institution teachers becomes the condition of 
providing high-quality educational services in distance; 2) distance learning environment should be developed: from a usual distance course, which contains high-quality learning content and innovative methods of digital communication, to powerful online platforms of educational institutions; 3 ) the innovative learning and teaching aids for distance learning (electronic textbooks and guides, digital learning resources, online excursions, virtual labs, high-quality computer tests, etc.) should be created.

It is clear that after finishing the quarantine restrictions, school learning will not return to the previous forms, the blended learning will dominate which will allow combining the digital pedagogical and technological innovations with the best experience of age-old face-to-face learning.

\section{REFERENCES}

[1] The research on the state of implementing distance education in Ukraine (March - April 2020), ProSvit, The center of innovative education, 2020, available at: http://prosvitcenter.org/doslidzhenniadystanciynoyi-osvity-2020

[2] Malik, Mubasher Hassan, Tabasum, Mirza (2021), The Digital Literacy in Teachers of the Schools of Rajouri (J\&K), India: Teachers Perspective, International Journal of Education and Management Engineering, Vol. 11, No. 1, pp. 28 - 40, 2021. DOI: 10.5815/ijeme.2021.01.04

[3] Beskorsa, O. S. (2017), Virtual learning environment Moodle as a means to organize blended learning in teaching practical phonetics of German language, Information Technologies and Learning Tools, volume 62(6), pp. 86-97. DOI: $10.33407 /$ itlt.v62i6.1832

[4] Havrilova, L. H. (2017), Specifics of the development of distance courses for musical-historical disciplines, Information Technologies and Learning Tools, volume 58(2), pp. 26-37. DOI: 10.33407/itlt.v58i2.1596.

[5] Kukharenko, V. M. (2019), Tutor of distance and blended learning: teaching guide, Milenium, Kharkiv, available at:

http://repository.kpi.kharkov.ua/handle/KhPIPress/42981.

[6] Chetwynd, F. and Dobbyn, C. (2011), Assessment, feedback and marking guides in distance education, Open Learning: The Journal of Open, Distance and e-Learning, volume 26(1), pp. 67-78. DOI: $10.1080 / 02680513.2011 .538565$

[7] Park, H. and Shea, P. (2020), A review of ten-year research through co-citation analysis: Online learning, distance learning and blended learning, Online Learning, volume 24(2), pp. 225 - 244. DOI: 10.24059/olj.v24i2.2001.

[8] Surma, T. and Kirschner, P. (2020), Technology enhanced distance learning should not forget how learning happens, Computers in human behavior, Virtual special issue, volume 110. DOI:10.1016/j.chb.2020.106390.

[9] Rozanova, V. A. (1999), Methodology of diagnosing and motivating to achieve the success of T. Ellers, Psychology of management, ZAO "Biznes-shkola "Intel-Sintez", Moscow, available at: http://amac.md/Biblioteca/data/26/03/Management/ Rozanova.pdf.

[10] Simonson, M. Smaldino, S. Albright, M. and Zvacek, S., (2003), Teaching and learning at a distance: foundations of distance education, 2nd ed., Merrill Prentice Hall, Upper Saddle River, NJ.

[11] Belshaw, D. (2011), The essential elements of digital literacies, available at: http://digitalliteraci.es/

[12]L. Havrilova, Y. (2017), Topolnik, Digital Culture, Digital Literacy, Digital Competence as the Modern Educational Phenomena, Information Technologies and Learning Tools, volume 61(5), pp. 5-15. DOI: 10.33407/itlt.v61i5.1744

[13] Emmanuel G. Dada, Abdulkadir H. Alkali and David O. (2019), Oyewola, An Investigation into the Effectiveness of Asynchronous and Synchronous Elearning Mode on Students' Academic Performance in National Open University (NOUN), Maiduguri Centre, International Journal of Modern Education and Computer Science, volume 11, no. 5, pp. 54-64. DOI: $10.5815 /$ ijmecs.2019.05.06

[14] Thomson, Thomson Job Impact Study: The Next Generation of Corporate Learning, Thomson, Inc., 2002, available at: https://mdavidmerrill.files.wordpress.com/2019/04/t hompsonjobimpact.pdf.

[15] Clark, D. Blended learning. CEO Epic Group plc, 52, Old Steine, Brighton, 2003, available at: https://ru.scribd.com/document/84278560/Clark-DBlended-Learning/

[16] Purnima, V. Blended Learning Models, available at: https://purnima-valiathan.com/wpcontent/uploads/2015/09/Blended-Learning-Models2002-ASTD.pdf

[17]Chin-Ting Chou, Chien-Pen Chuang and Bin-Yong Zheng (2013), The Study of Blended Learning on a Vocational High School in Taiwan, International Journal of Modern Education and Computer Science, volume 3, pp. 1 - 7. DOI: 10.5815/ijmecs.2013.03.01. 
[18] Barabash, O. Musienko, A. Hohoniants, S. Laptiev, O. Salash, O. Rudenko, Ye. and Klochko, A. (2021), Comprehensive Methods of Evaluation of Efficiency of Distance Learning System Functioning, International Journal of Computer Network and Information Security, volume 13, no. 1, pp. 16-28. DOI: $10.5815 /$ ijcnis.2021.01.02. 